\title{
Imaging in Oncology a new beginning has just begun...
}

Citation for published version (APA):

Beets-Tan, R. G. H. (2010). Imaging in Oncology a new beginning has just begun.... Maastricht University. https://doi.org/10.26481/spe.20100628rb

Document status and date:

Published: 28/06/2010

DOI:

$10.26481 /$ spe.20100628rb

Document Version:

Publisher's PDF, also known as Version of record

\section{Please check the document version of this publication:}

- A submitted manuscript is the version of the article upon submission and before peer-review. There can be important differences between the submitted version and the official published version of record.

People interested in the research are advised to contact the author for the final version of the publication, or visit the DOI to the publisher's website.

- The final author version and the galley proof are versions of the publication after peer review.

- The final published version features the final layout of the paper including the volume, issue and page numbers.

Link to publication

\footnotetext{
General rights rights.

- You may freely distribute the URL identifying the publication in the public portal. please follow below link for the End User Agreement:

www.umlib.nl/taverne-license

Take down policy

If you believe that this document breaches copyright please contact us at:

repository@maastrichtuniversity.nl

providing details and we will investigate your claim.
}

Copyright and moral rights for the publications made accessible in the public portal are retained by the authors and/or other copyright owners and it is a condition of accessing publications that users recognise and abide by the legal requirements associated with these

- Users may download and print one copy of any publication from the public portal for the purpose of private study or research.

- You may not further distribute the material or use it for any profit-making activity or commercial gain

If the publication is distributed under the terms of Article $25 \mathrm{fa}$ of the Dutch Copyright Act, indicated by the "Taverne" license above, 


\section{Maastricht University}

Prof. Dr. Regina G.H. Beets-Tan

Faculty of Health, Medicine and Life Sciences

Imaging in Oncology

a new beginning has just begun...

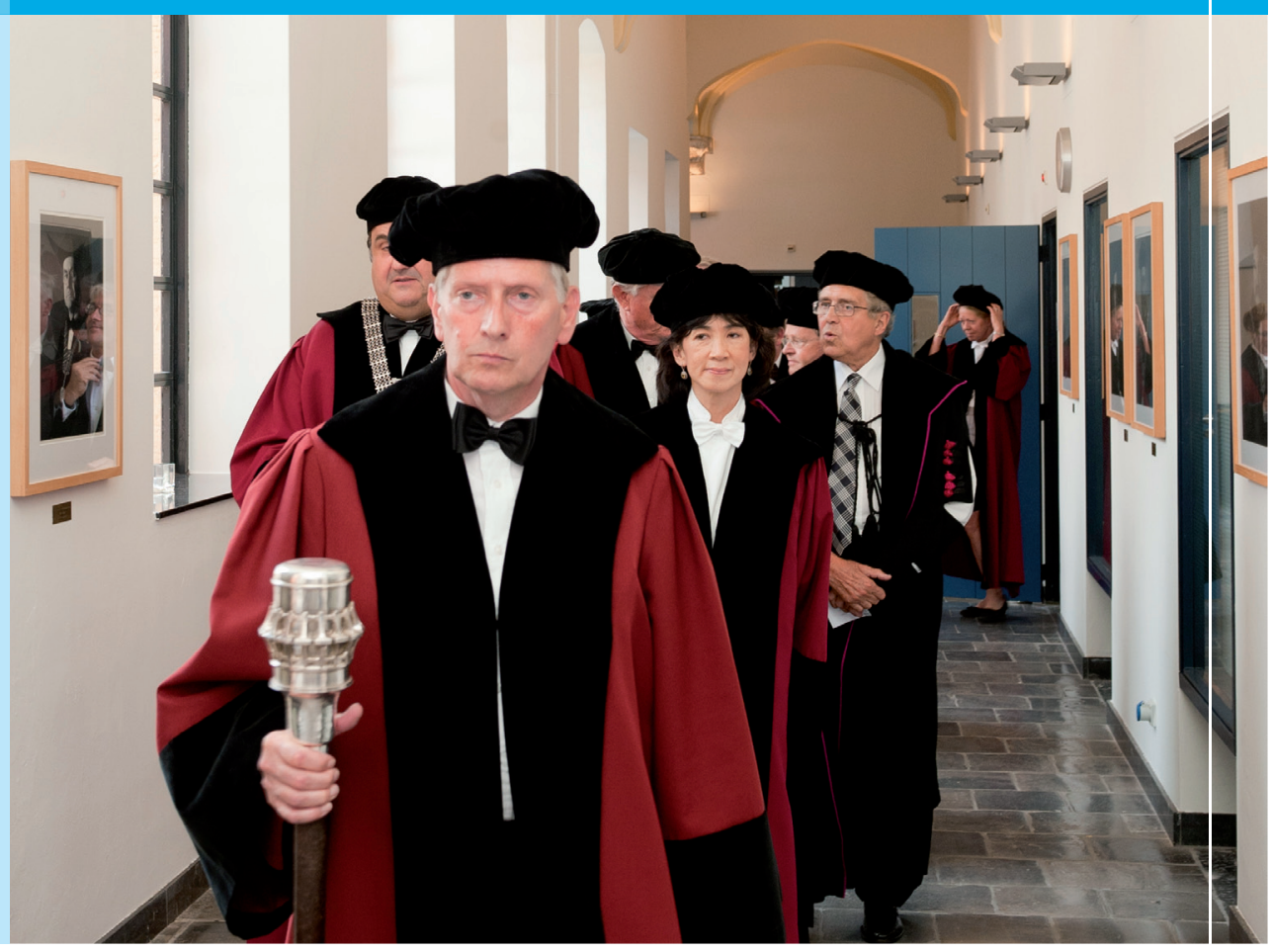


Imaging in Oncology

a new beginning has just begun... 


\section{Colofon}

Print and Design: Océ Business Services, Maastricht

ISBN: 978-905-681-357-4

NUR: 876

Alle rechten voorbehouden. Niets uit deze uitgave mag worden verveelvoudigd, opgeslagen in een geautomatiseerd gegevensbestand of openbaar gemaakt worden, zonder voorafgaande schriftelijke toestemming van de auteur of uitgever. 


\section{Imaging in Oncology a new beginning has just begun...}

Inaugural Lecture

Maastricht, 28 June 2010

Prof. Dr. Regina G.H. Beets-Tan 
Highly distinguished prorector, dean, Highly distinguished colleagues professors,

Dear colleagues,

Dear family and friends, Ladies and gentlemen,

When Roentgen discovered the X Rays 115 years ago, a giant step was made in mankind. For the first time we were able to look at diseases. But spectacular advances in imaging were only made during the last 40 yrs. Hounsfield, the discoverer of Computed Tomography (CT), Mansfield and Lauterbur, discoverers of Magnetic Resonance Imaging (MRI), were all great men that has preceded us.

In 2001 healthcare providers in the US were asked what they thought were the 5 most important developments in medical technology in the last 30 yrs. Their answer was $\mathrm{nr}$ 1: CT and MRI, $\mathrm{nr} 2 \&$ 3: balloon angioplasty and intervention and $\mathrm{nr}$ : mammography.

Why mammography? Radiologists not only deal with patients but also with healthy people. Mammography is used in population based breast cancer screening and reduces cancer death. We have learnt from Prof Boetes in her inaugural lecture that also MRI has potential for future breast screening. Bowel cancer screening is on its way. We can screen with fecal occult blood test, with endoscopy, and even with imaging. We fly through the bowel and search for polyps like the endoscopist does but now with $\mathrm{CT}, \mathrm{CT}$ colonography. Prof Jaap Stoker from AMC does a lot of great work in CT colonography to determine its cost efficency for bowel cancer screening.

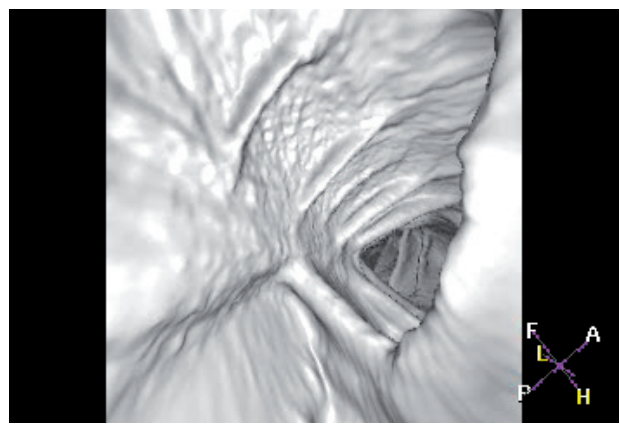

CT colonography, courtesy J. Stoker, AMC. 
So we can screen and prevent cancer death. But population screening in bowel cancer is not yet common practice. Because it is a matter of choosing how we we want to spend the money.

Why CT and MRI? I'll show you why. The oncology research here in Maastricht is focussing on 3 of the 5 big killers: lung, breast and colorectal cancer.

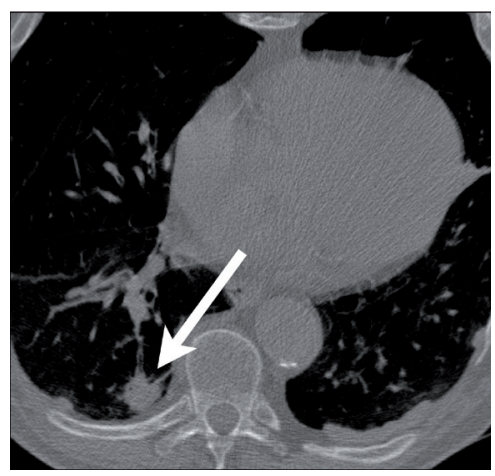

CT of a patient with a lung tumor.

Here a lung tumor on CT. The tumor is attached to the chest wall and there are tumor depositis nearby. This is the patient's chest X Ray. It is very difficult to find the tumor. You can easily overlook it. So CT helps for better detection of lung tumors.

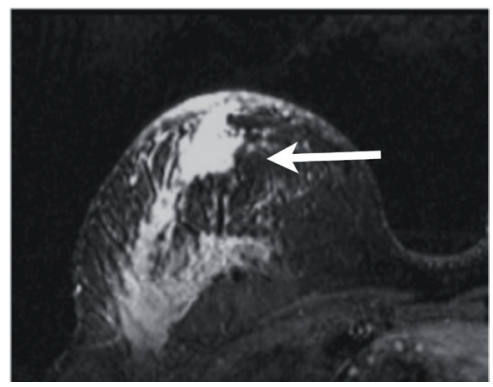

MRI of a patient with breast cancer.

Here a mammography of a patient with palpable lump in her breast. This could be a tumor. Here is her MRI. Indeed the tumor is confirmed but MRI gives more information. It shows us that the tumor is large and that it extends to the chest wall. 


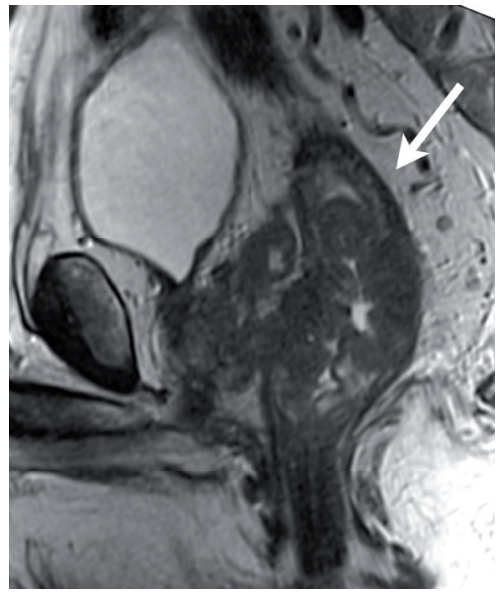

MRI of a patient with bowel (rectal) cancer.

Here is a patient with bowel cancer, a rectal cancer. We used to detect it with barium enema studies. Here an irregular wall, a sign that there may be a tumor here. But we use MRI today and you can see much more. Very small tumors can now be seen with modern imaging.

One of our research focus is to test new MR contrasts that can help us identify small tumors as in small lymphnodes. We can see them now on MRI and even tell you that it maybe a good lymphnode or a bad. The answers that we can give today are so different than during those days when we did not have CT or MRI.

\section{Personalized medicine and integrated diagnosis}

For a long time cancer treatment was standardized treatment for a large cohort of patients. Standardized treatment does not take into account that there are differences among patients and differences among tumors. New molecular technologies now give us more information on the patient's individual tumor profile, the protein, genetic and metabolic information of the tumor. This, combined with patient's medical history, is used to tailor the treatment to the need of each individual patient. This is called personalized medicine.

Imagine two terrorists in a large crowd of people. We want to kill these terorrists. We can do it in two ways. We can drop a bomb, for sure we will hit the target, the terrorists, but we will also kill the innocent. Or we can 
narrow our target and focus only on the two terrorists. But to do so we need to use each and every tool that we have obtain our goal. In such as situation we will kill the bad but save the good.

This is what personalized medicine is all about. It is " the right treatment for the right person at the right time". Personalized medicine increases the therapeutic index, decreases the number needed to treat and reduces the cost. In the pursuit of personalized medicine we need to develop new imaging tools that can help us understand the pathways of new cancer treatment and help for better selection of the patients.

We can now image detailed morphology but we will learn that morphology alone is not sufficient. Changes in morphology do not occur at the same speed as changes in biology. So we need to image in a different way, image tumor biology, tumor metabolism, its genetic and protein information.

Imaging diagnosis will from now on not be about straight or clearly defined diagnosis, but will be about integrated diagnosis. Integrating imaging data with tumor molecular profile to generate the most probable diagnosis.

\section{Modern cancer imaging}

We are entering a new area of imaging, the area of Molecular Imaging (MI). $\mathrm{MI}$ is expecting to really change the way we diagnose, treat, and do the follow up of cancer patients. Among the most promising MI methods today is PET, Positron Emission Tomography. Here is an FDG PET-CT of patient with lymphoma. That is PET combined with CT. FDG is a glucose tracer most used in oncology PET imaging, fluorodeoxyglucose $\left({ }^{18} \mathrm{~F}\right)$. The principle is that tumor cells have a higher glucose metabolism than normal cells. This is why they take up FDG. It is amazing how imaging can tell the medical oncologist how the tumor is responding to his treatment. 


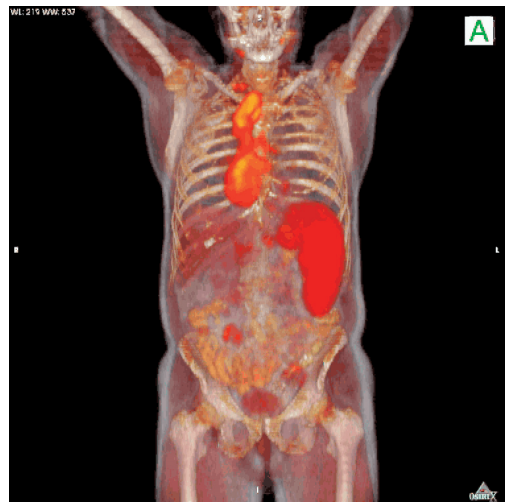

FDG PET-CT of a patient with lymphoma, courtesy E. Rummeny, Univ Hospital München.

But not all cancer types are visible on FDG PET because not all takes up FDG in the same way. Fortunately there's a menu of PET tracers today and these are just a few. 18 Fluoride PET tracers, promising in oncology.

Here the bone scan of a patient with metastases from his prostate cancer. The dark spots are the metastases. On the right is his 18 Fluoride PET scan. Many more lesions can be seen. It is frightening how many lesions we see today that we have missed yesterday as we can image more precisely. Here the FDG PET of two patients with metastases from breast cancer. Both breast tumors had estrogen hormone receptors on their tumor cells. So when they develop metastases they can be treated with a drug that suppresses the estrogen receptor. Following this treatment, patient 1 showed excellent response on FDG PET. Patient 2 no response at all. How can it be? Well we know: if the breast cancer is estrogen receptor positive (ER positive), the metastasis must be ER positive too. But imaging clearly tells us that this is not true at all. Here is an estrogen receptor PET scan using another PET tracer 18 Fluoride Estradiol Tracer (FES PET). This tracer binds to the estrogen receptors of a tumor cell. Patient 1 her metastasis had estrogen receptors and as you can see from her FES PET, the receptor suppressing drug binds to the receptors and kill the tumor cells. That is why patient 1 shows response. Patient 2 her metastases did not have estrogen receptors. So an ER suppressing drug would not bind and thus not work in this patient. That is why there is no response in patient 2 .

This is a very intelligent therapy that requires intelligent imaging. Imaging that helps clinicians to understand the pathways of their treatment: diagnostics being used to guide therapeutics. 
MRI is the king of kings of all imaging tools for detailed morphology imaging, so the best way to visualize tumors. Futhermore it does not expose patients to radiation. Because we are dealing with cancer patients and many now survive their cancer, it is not unusual that we perform over $30 \mathrm{CT}$ scans in cancer surveillance. When you're young that is a lot of radiation. MRI is very diverse. It gives detailed morphology but also gives detailed functional information.

We have perfusion MRI. Tumor growth depends on microvessels, angiogenesis. We can see microvessels because we can monitor these with MRI by quantifying the kinetics of contrast that passes the lumen. It allows us to see the effects of antiangiogenic cancer drugs.

You've seen receptor imaging with PET, but it will also be receptor imaging with MRI. Molecular imaging using MRI is a focus of preclinical research in our department. The team of Walter Backes succeeded in developing MR contrast that homes to receptors of tumor microvessels. Another potential tool for monitoring the effect of antiangiogenic drugs. We have MR spectroscopy. MR spectroscopy is metabolic imaging, like $\mathrm{PET}$, but here differences in spectral patterns tell us whether it is tumor or normal tissue .

You've seen whole body imaging with PET, but here is whole body imaging with MRI.

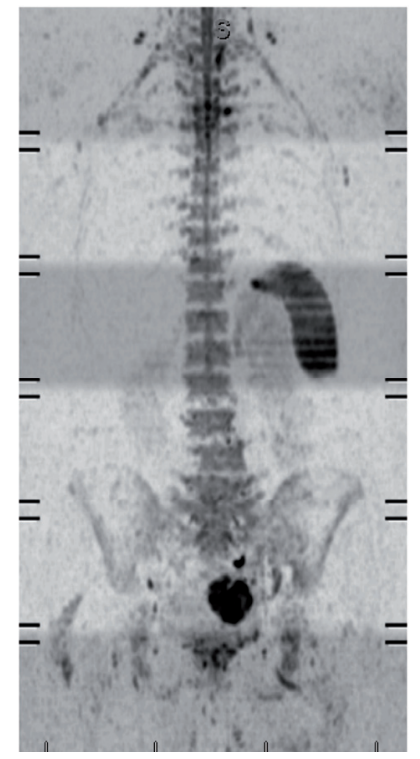

Whole body imaging with diffusion MRI 
It looks like PET but it is Diffusion MRI. Diffusion MRI tells us which is tumor and which not because it can capture the differences in movements of water molecules in tumor and healthy tissue. Unlike PET, it does not expose the patient to radiation. And you can even display it in every way that makes you more comfortable to look at the lesion.

We are developing technology continuously. There will be PET and MRI in 1 machine: PET- MRI. These are fusion images but PET- MRI for oncology will soon be reality. PET and MRI, the cornerstones of cancer imaging now and in future. They are complementary rather than competitive and combined they give the best of both worlds, molecular and morphology imaging.

Interventional radiologists in oncology use minimal invasive ways to kill tumor cells. Embolizing of liver tumors is one example. Cutting of tumor blood supply by clogging the vessels with beads. At Memorial Sloan Kettering Cancer Center, where my husband and me had the privilege to work during the past year, interventional radiologists use 3 dimensional images that they generate during the interventional procedure. It helps them to learn the consequences of his actions. When they do it wright and position the catheter here, the tumor vessels, will be clogged. But when they position the catheter there, then these vessels will be clogged which are normal liver feeding vessels, so normal liver will be damaged.

We also do biopsies. Take tumor samples for tissue analysis. That can be very difficult in small organs like prostate. But we have imaging to guide us, US but also MRI. Here you can see how MRI guides our needle to exactly hit our target the tumor in the prostate.

\section{Computing and augmented imaging}

More sophisticated imaging is on the horizon to guide us in intervention. Imaging by computing. Virtual reality that shows us where exactly we are during the procedure.

There is robotic surgery. It is an amazing piece of technology where robotic hands can extend the surgeons hands and scales down the motions to microanatomy level and magnifies the field in 3 Dimensions. It is often performed in prostate cancer surgery. Imaging by computing will allow the surgeon to prepare his complex surgery beforehand and limit the moments where he might be unpleasantly surpised by anatomy. 
Computing images will help him not only before the surgery but also during the procedure. Because there will be augmented imaging. Imaging that overlays the virtual anatomy of the patient and the real anatomy. It can tell the surgeon where exactly he is during the surgery.

Computing images and augmented images. Those will be the images of tomorrow that we' re now only dreaming about.

\section{Collaboration}

The matrix for success in cancer medicine is multi-disciplinary team approach. Multidisciplinary teams (MDT) consist of surgeons, radiotherapists, medical oncologists subspecialized in certain cancer types. They manage the patient together as a team of experts. Expert treatment requires expert diagnosis. It is therefore inevitable that radiology and the radiologist's role change. From technology centered to patient centered, from general to subspecialized radiologists. This change has already taken place in cancer imaging. It is in the field of oncology that our imaging can so much influence treatment decision making. I want to illustrate it with the following.

MR image of a patient with rectal cancer. Here is the tumor. It extends to the surgeon's resection margin, over here. What happens when we don't use imaging? The surgeon would cut right through the tumor and leave tumor remnants behind. The patient is now at risk for a recurrence and distant spread. But because there is imaging the expert team decides not to resect it right away but first irradiate the tumor. Then the radiologist points at this node, he thinks it might be involved. This node is in the surgical field so that's not a problem, it will be removed anyway. But this node is outside the surgeons field. If there was no imaging we would have overlooked the suspicious node. Now the team can tailor their treatment to this patient's need. The radiation oncologist decides to give a higher dose to the node to sterilize it and the medical oncologist adds chemotherapy to minimize the risk for distant tumor spread. This is cancer imaging that truly contributes to treatment decision making.

The use of modern imaging, no matter how fancy, would not make any sense if it does not impact patient's outcome. The use of imaging in medicine is worldwide expanding and so are the costs. So when new imaging technologies have been validated the next wright step is to study this technology within the context of a clinical trial with patient's outcome as the primary endpoint. Only this will determine the true value of the diagnostic tool. 
We performed such a study in our region. We scanned all rectal cancer patients with MRI, we let MRI tells us which are the good, the bad and the ugly tumors and gave different treatments base don the MR findings. The outcome improved: the local recurrence rate decreased from $40 \%$ in the old days, dropped down to $11 \%$ with better surgery and further down to well below $5 \%$ with better imaging. If you look at this map, it is striking that in our catchment area there were less rectal cancer deaths when we started to use MRI in all patients. Obviously this is due to many factors, not only because of better imaging but also because of better surgery, better radiotherapy, better chemotherapy as well. So it's clear that we have to get radiologists in the middle of the MDT. This is the only way we can keep up with the high requirements in cancer imaging.

Close Collaboration with clinicians, it may sound so obvious, yet it's not. I remember very well when in 2003, not even a long time ago, it was dicussed with in the european radiology society whether or not we would benefit from clinical education in our meetings. Radiology was then not ready. But it's changing now. This year multidisciplinary teaching courses in cancer were organized for the very first time at the annual meeting of the European Society of Radiology (European Congress of Radiology, ECR 2010) and because of the growing need for clinical education, it will become one of the main educational streams in future ECR's.

We are becoming more aware that we cannot practice radiology in isolation. When we subspecialize we will lose general knowledge. But we will gain new others and improve our quality. We can be of even greater value than ever before, because we combine our skills in technology with know how in therapy.

But to become good, we need to invest. Because to offer a wright answer to a question we first need to understand the question. So I encourage colleagues radiologists to seek education not only inside but also outside our specialty. These are the moments where we get to know the dynamics in the specialties around us, where we get to understand their questions.

There are many occasions to do so. The Dutch Colorectal Cancer Group (DCCG) represents the essential collaboration between the different disciplines in research and clinical practice and aims at monitoring and improving the quality of diagnosis and treatment of patients with colorectal cancer. The group organizes dutch and international meetings where we learn from each other, from clinicians from the different disciplines. I am happy to see an increasing number of colleagues attending 
these multidisciplinary meetings among whom many radiologists. But other occasions will soon follow. Collaboration is already starting to take place at the level of societies. The European Schools of Radiology and Radiation Oncology will organize joint postgraduate courses for radiologists and radiotherapists. The European Society of Abdominal Radiology (ESGAR) has teamed up with the United European Federation of Gastroenterology and has representatives in educational and future trend committees. The ESGAR has also started collaboration with the European Society Digestive Oncology. Radiology is ready to get in the middle of the MDT.

\section{Ownership}

This brings me to the following. Exchange of knowledge means share of knowledge. Until now imaging facilities have redominantly remained in the domains of the radiologist. Imaging has so far mainly been used by radiologists and nuclear physicians. But this will change, especially in oncology. A change in the organization of hospital departments has in fact already happened years ago. Numerous facilities in clinics are collectively used by different specialties: operating rooms are not owned by surgeons, Intensive Care Units have become independent of cardiology or neurology. So there is no specific reason why imaging facilities should not be located elsewhere in hospital and why imaging should not be used by clinicians.

Radiation oncologists. They use imaging. PET helps them for precise definition of their tumor target and this is important for modulated radiotherapy.

Surgical oncologists. They use imaging. This is the setup of an operating theatre for cancer surgery in Maastricht. Time has passed that surgeons only read reports and did not look at images. A picture tells us more than thousand words and it is so true also for surgeons. But to use the pictures they need to understand these.

As much as we learn from clinicians, we need to be willing to teach back. We cannot monopolize imaging because we cannot monopolize knowledge. We can invent and investigate, but thereafter we need to share. This is what happens in research. But this should also happen in treatment, in imaging. 
Because think about this. "Do we really own radiology?". What in fact is radiology? Yes, you can own a CT machine or an MR equipment but can you own knowledge? If you don't like the idea that clinicians become knowledgeable don't become protective. Don't let fear dictate how you act, because:

Nothing in life is to be feared....it is only to be understood.

(Marie Curie)

So don't waste time and energy in turf battles. But invest and excell in knowledge. Because knowledge is power and knowledge gains respect. It is without doubt that imaging technology and diagnosis making processes remain the mainstay of radiology. We invent, investigate, optimize and monitor new imaging technologies. We diagnose. These are skills that are truly ours, for which our colleagues really need us and above all respect us.

\section{Reorganize}

Radiologists especially those working in the field of oncology process an increasing number of scans, learn about new molecular technology, interact with clinicians, learn about therapy and teach back on imaging. It is obvious that no single person can master this all. With subspecialization quality is high but organization even more complex.

So is it time now to change? Change the way we organize our work, our department, and our specialty? Often when the question arises whether a change is needed, it is time to change.

How to do this? Obviously there are many ways here are just a few. Training more radiologists is one priority but only solves the problem in the long run and is certainly not without increasing cost for society. Outsourcing of images to outside centers that report images from remote (teleradiology) could work but not in cancer imaging, where the focus is on multidiscplinary interaction.

The use of computer programmes to assist us: Computer aided diagnosis. We, radiologists in oncology, spend endless of hours deciding based on 1 single size diameter whether the tumor shows response, yet we know logically that our size measurements do not always indicate tumor response. Not to speak about the high variability in reading results among different readers. You must admit that if you, colleague oncologists, look 
at these images would you rather base your decision - whether or not you continue chemotherapy- on this single size measurement, where there is no response or on this volume measurement that shows clear response?

But volume measurements are time consuming. So we need computers to assist us and free our time. Not at all pretending that it will substitute radiologists. We will always remain responsible for the final interpretation of an image.

Reallocating tasks to physician assistants or radiology technologists: radiology assistants. Radiology assistants work side by side and under supervision of a radiologist in the diagnosis making procedures. The study of professor van Engelshoven and Dr. Karin Flobbe in Maastricht has shown that this concept could work to free up the time of the breast radiologist. Their results showed that in breast cancer imaging radiology assistants can accurately select mammographies that have no abnormality, leaving only the ones that need further evaluation to the breast radiologists. No need to say that it should be implemented only under close monitoring and with regular training.

Reallocating tasks to physicists - biomedical engineers - informatician technologists. There will be increasing quantifiable data from MI. Increasing computing and augmented imaging. It is high scientific technology know how that is not our expertise. These technology experts can alleviate our tasks by working side by side with us in clinical practice. In the Netherlands a study that combines the bachelors degree in technology science with a masters degree in medicine will result in the first technical-medical doctors to enter radiology in the coming years. But untill this will become reality and untill the shortage of radiologists will be filled, the demand will be high to have others to alleviate our tasks.

Reorganizing the imaging specialties, radiology and nuclear medicine. While in the US, nuclear medicine and radiology are located within the same department, in Europe they are separate and totally autonomous. The two specialties have similarities and differences. They both offer diagnosis and treatment and they both use radiation. The difference is that radiology focuses more on anatomy imaging while nuclear medicine on metabolism and biology imaging. Our imaging specialties are thus complementary and not competitive.

With the increasing use of PET-CT in oncology and soon also PET-MRI the demarcation between the 2 specialties will become less evident. Board certified nuclear physicians and radiologists already seek education in each other's field and double registrations are increasingly taking place. 
Obviously double registration is an undesirable situation and turfbattles in diagnostic equipment even more.

It is therefore time to revisit our specialties and recognize the synergy when the two merge into one. The sound base upon which this can be realized is in specialty training. Disease oriented training programmes in radiology and nuclear medicine incorporate periods of exchange in training between the two specialties. Future will learn that disease oriented training in clinical, anatomical and molecular imaging will fully integrate and will result in the new generation imaging diagnosticians.

Today's radiologist will be tomorrow's imaging specialist. Imaging in Oncology, a new beginning has truly begun...... 


\section{Thank You...}

When 2 years ago I was appointed the position of professor in Oncology Imaging at the medical faculty of Maastricht University, I was aware that I could not have achieved this position without the support and efforts of many, many people. And that I can only fulfill this challenging task with their continuous support.

Aware that I cannot be complete I would like to thank all those that have been with me. I wish I could name them one by one, but that is impossible. My gratitude goes to all of you.

First of all I thank God, who gave me the gift, the endurance and the wisdom.

I thank the patients, who even during the most difficult time of their lives, were able to give to others. You are the reason for which I will continue my work.

I would like to thank the College van Bestuur of the University of Maastricht, the rector, the prorector, the dean of the Faculty of Health, Medicine and life science, Prof Martin Paul; I thank the Board of Directors of the University Hospital Maastricht for their trust in me.

Prof van Engelshoven, emeritus professor and former chair of the radiology department at the University Hospital Maastricht. Dear Jos, you were the one who taught me the tricks of the trade, in radiology and in research. I pay tribute and respect for your vision as a leader. You accompanied me along the journey and gave me freedom to grow. It is because of you that I am in this position. I deeply thank you for your trust in me.

Prof van Waes, emeritus professor and former chair of the radiology department at the University Hospital Utrecht. Dear Paul, you opened the door of radiology for me. You showed me the way into this specialty. Thanks for your unconditional trust in me. Thanks for being a mentor and a friend.

I am honored with the presence today of highly distinguished guests, from different universities in the Netherlands and abroad. Thank you so much for attending my inauguration. 
Colleague professors in surgery, in digestive oncology, in radiation oncology from the Unversity Hospital Leuven. It is very rewarding to work with you both in education as well as in research. I hope to consolidate and expand our collaboration.

Thanks especially to you here present, my colleagues and former trainers in radiation oncology. You introduced me into the world of Oncology and I thank you for that.

My colleague board members of the ESGAR, of the DCCG, present here professor vd Velde, dear Cock, of the Dutch Society of Radiology, present here the president, professor Laméris, dear Han, thank you for the opportunities given to me to realize my mission for radiology. Thank you for our pleasant collaboration in work and for our friendship outside.

I thank my colleagues in the audience from far and abroad. It means a lot to me that you have traveled the long way to be here with me today.

My sparing partners, clinical colleagues in so many multidisciplinary teams in our hospital and in the oncology center. The research partners and the directors of the oncology research school. There are too many to mention one by one. My sincere gratitude for our excellent collaboration, for your trust in me to build oncology imaging in Maastricht.

A "thank you" goes to the department of radiology in Maastricht, each and every person who have contributed to my work, the secretarial office, my personal secretaries, technologists, physicists, all residents.

Professor Wildberger, present chair of our department, Joachim, I wish you all the luck in building the department and I surely hope we can build together.

Prof Boetes, Carla. Years ago we expressed our wish to work together. Our wishes came true. I am so glad that you are now here with me in Maastricht.

My sincere gratitude to the attending staff of radiology, my colleagues: without your support I could not stand here today.

A special word to Dr de Haan, dear Michiel, thank you for being my colleague and friend. To Dr Cappendijk, dear Vincent and to Dr Bakers, dear Frans, I cannot express in words my gratitude for your unconditional 
support. I hope we will continue working together as a team for a long, long period.

Many many thanks to my research team, students and PhDs : Quido, Roy, Sanne, Elleke, Max, Doenja and Monique. It is a real joy working with you. You are the ones who - when the challenge seems the hardest, the problems insoluble and everyone else would shake their heads - say: "Let's Go". Your ambitions are high and my wish is to make your professional dreams come true.

My family and beloved friends, many of you have come from far to be here with me. I cannot express my feelings. You mean a lot to me.

My inlaws, my father,my late mother in law, my sisters. Thanks for being such a great family.

Dear Renate, dear Roger. I am so privileged to have you as my sister and my brother. I am very proud of you and of your families.

Dear mom, unfortunately, dad is no longer with us. I want to thank you both for every moment in life, for giving me a future, for being my councellor, for your believe in me. Your love is unconditional and goes beyond all titles and achievements.

Dear Geerard, dear Nathalie.

Geerard, if it wasn't you that was with me in my life, I could not have made it. Every word that I say is not enough to express my love. You are my power.

Nathalie, what can I say? When I wrote down these words of thanks, you looked at me and said: "you don't write thanks, mammie, you pay thanks from within your heart". You rock baby. You know that we both are proud of you, and will always be there for you because you are our number one.

I have spoken. 
